\title{
UMA NOVA DIMENSÃO DA DIVERSIDADE NAS ORGANIZAÇÕES
}

\section{Carlos Osmar Bertero}

Professor da Escola de Administração de Empresas de São Paulo, Fundação Getulio Vargas - São Paulo - SP, Brasil

carlos.bertero@fgv.br

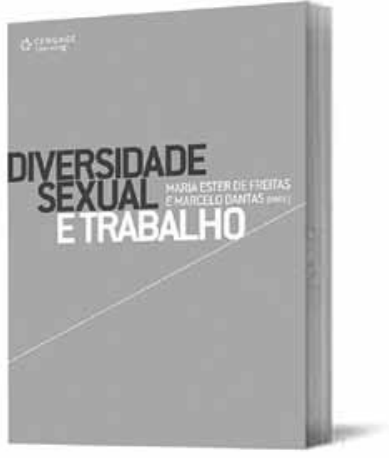

\section{DIVERSIDADE SEXUAL NO TRABALHO}

Maria Ester de Freitas e Marcelo Dantas (Organizadores). São Paulo, Cengage Learning, 2012, XI, 379 p.

O livro que aqui se resenha não deixa de ter um caráter pioneiro na literatura sobre Administração, uma vez que a gestão da diversidade chegou a subsidiárias brasileiras a partir de decisões corporativas tomadas no exterior e às empresas brasileiras à conta de nosso tradicional mimetismo.

Algumas considerações preliminares devem ser feitas. Primeiramente, o texto é exemplo de trabalho engajado. Em nenhum momento restam dúvidas de que os diversos autores que redigiram a introdução e os doze capítulos são partidários da diversidade e militam para que ela se torne presente nas organizações. Segundamente, o livro considera as questões de gênero, mais antigas, integrantes da diversidade. O pressuposto é que as organizações tradicionalmente eram consideradas locais de trabalho masculinos, onde haveria lugar para mulheres apenas em posições subalternas. Consequentemente, abrigar mulheres em todas as posições e níveis hierárquicos é entendido como prática da diversidade. E o terceiro pressuposto é que a diversidade é benéfica, ou seja, se ela existe na sociedade, deve também estar presente nas organizações. Além do mais, a diversidade é a soma de talentos e competências, não reduzindo o potencial criativo e a eficiência e eficácia administrativas.

Acredito que os organizadores enfrentaram alguma dificuldade em agrupar os diversos capítulos, dada a sua própria diversidade, em termos de temas, metodologias e gênero literário. Temos trabalhos empíricos que utilizam metodologias tanto quantitativas como qualitativas. Tentarei efetuar um reagrupamento que não segue $\mathrm{o}$ do livro por questões de formatar esta resenha, sem pretender criticar ou corrigir a organização dos textos feita pelos organizadores.

Primeiramente, temos os capítulos teóricos na forma de ensaio. Aqui agrupo a "Introdução" de Marcelo Dantas, e os capítulos sobre
"Sexualidade e trabalho na visão da psicanálise" de José Roberto Heloani e Claudio Garcia Capitão; "(Re) Descobrindo as masculinidades" de Claudia Sirangelo Eccel e Rafael Alcadipani; "Corpo, pessoa e gênero" de Maria Tereza Flores-Pereira; e "Além dos estigmas profissionais" de Luiz Alex Silva Saraiva.

Segundamente, colocaria os capítulos que se apoiaram em dados secundários. Aqui se encontra o texto de Maria Ester de Freitas, "O sexo no trabalho intelectual".

Finalmente, teríamos um terceiro grupo, onde estão os trabalhos baseados em dados primários gerados ou coligidos pelos próprios autores. Aqui se encontram o capítulo "Em busca de uma pedagogia gay no ambiente de trabalho" de Marcus Vinicius Siqueira e Augusto Andrade; "Travestis e transexuais no mundo do trabalho" de Hélio Arthur R. Irigaray; "Os donos e as donas da cozinha" de Lívia Barbosa; "Gênero e o trabalho com a morte violenta" de Neusa Rolita Cavedon; "Gênero no ambiente acadêmico" de Sylvia Constant Vergara e Ana Paula Cortat Zambrotti Gomes; "Maestria em artes e ofícios populares: uma questão de gênero" de Tânia Fischer e Rodrigo Maurício Freire Soares; e "Mulheres gerentes entre o empoderamento e o teto de vidro" de Marlene Catarina de Oliveira Lopes Melo.

A "Introdução" de Marcelo 
Dantas contem mais do que habitualmente encontramos nas notas introdutórias a coletâneas. Ele não resume nem descreve os diversos capítulos, mas se detém para contextualizar o sentido da diversidade sexual num país e numa cultura como a brasileira, plena de ambivalências ao tratar da sexualidade. O primeiro capítulo apresenta a possibilidade de se utilizar o referencial psicanalítico no tratamento da sexualidade e da sua diversidade, mas não é adotado como linha mestra para os demais ensaios. O capítulo sobre as várias leituras e versões da masculinidade é uma boa advertência contra o estereótipo do masculino, que na sua forma mais caricatural chega ao machismo. Afinal, embora continuemos a viver numa sociedade patriarcal, não há como negar que se trata de um patriarcado mitigado e "abalado" por várias transformações, dentre as quais a ascensão da mulher. O capítulo seguinte, ao falar em corpo, pessoa e sexo, estabelece parâmetros básicos para o entendimento dos diversos temas que permeiam o livro. Não é um ensaio inovador, mas coloca as principais ideias que norteiam o tema da diversidade, especialmente as voltadas ao gênero. O capítulo sobre estigmas profissionais retoma um clássico de Erving Goffman, e o aplica não só para o entendimento da homossexualidade, mas para as outras formas de diversidade sexual. Afirma que os estigmas são aplicados a profissões diversas, não só às profissões execradas, mas para considerar que certas profissões são mais adequadas a pessoas de um sexo e que outras podem comportar homossexuais.

A seguir, temos o capítulo em que Maria Ester de Freitas nos mostra, recorrendo à história mais recente do desenvolvimento científico, que as mulheres tiveram maior participação do que normalmente lhes é creditada. Excelente lembrança, porque a construção social da inferioridade feminina sempre colocou a mulher como possuindo menos conhecimento do que o homem. A construção do saber sempre foi considerada tarefa masculina.

No terceiro grupo de capítulos, temos o que lida com a questão de uma pedagogia gay para o ambiente de trabalho. É um trabalho com características mais marcadamente militantes e onde se busca abrir espaço para gays em organizações empresariais. O trabalho faz referência a iniciativas bem- sucedidas em uma empresa. O capítulo sobre travestis e transexuais é um registro interessante de um tipo de diversidade sexual que normalmente relega os indivíduos a profissões sexuais. O travesti e o transexual em posições organizacionais e administrativas são um tema para reflexão e ainda merecedor de trabalhos adicionais. O texto mostra que a presença destes em empresas é ainda objeto de rígida intolerância. O capítulo de Neusa Cavedon sobre gênero no Departamento de Criminalística do Instituto de Perícias do Rio Grande do Sul é um dos melhores da coletânea. Tema, esmero metodológico e uso adequado das informações, respaldadas por referencial teórico sempre adequado. O capítulo sobre "Gênero no ambiente acadêmico" traz a metodologia pouco utilizada de um quase experimento e faz uso de técnicas projetivas. Os achados não são surpreendentes, mas documentam e fundamentam uma situação existente que é ainda a preferência por homens no provimento de posições de gestão na academia. O capítulo sobre "Os donos e as donas da cozinha" aborda tema interessante e pouco versado na Administração. Como tudo o que vem da autora, é muito bem elaborado, faltando algum esclarecimento metodológico sobre a obtenção de trechos de entrevistas citados e incorporados ao texto. Certamente, o lugar da mulher não é mais na cozinha, e quem deve lá estar é, hoje, a área nublada de onde a tradicional divisão sexual do trabalho desapareceu. O capítulo sobre "Maestria em artes e ofícios populares" é o único da coletânea que nos retira do universo organizacional e nos leva para a esfera doméstica e comunitária. O trabalho usa informações obtidas a partir de uma comunidade artesanal no Território do Sisal, no estado da Bahia. Os autores mostram como o artesanato serve ao desenvolvimento da própria identidade e como ele acaba sendo atividade feminina. O derradeiro trabalho da coletânea é sobre o tema do "teto de vidro e empoderamento (empowerment)". Os dois conceitos são revistos e analisados, e a autora utiliza informações coletadas junto a 20 gerentes de ramos de atividade empresarial diversa. Embora constate que nossa cultura continua sendo marcadamente masculina, por outro lado, dados secundários mostram que a presença de mulheres em posições de comando em organizações empresariais vem aumentando. Infelizmente, o teto de vidro ainda permanece.

O livro pode servir ainda de estímulo para estudos de diversidade. Lembremos que as questões de gênero, que tiveram no movimento feminista dos Estados Unidos, na década de 1960, um ponto de inflexão, não lograram gerar grande interesse em nosso país. A diversidade é nossa desde o início da nacionalidade, mesmo antes que tivéssemos aqui organizações empresariais, e por isso merece o nosso cuidado. Certamente, existem ainda muitos aspectos da diversidade a ser abordados. Um que pode ser muito fecundo é a diversidade existente entre nós pela imensa distância entre as classes sociais. 